\title{
Relationship between clinical symptomatology on the isolation of Salmonella Gallinarum of japanese quail (Coturnix coturnix)
}

\author{
[Relação entre a sintomatologia clínica no isolamento de Salmonella Gallinarum
} de codornas japonesas (Coturnix coturnix)]

\author{
R.C. Rocha-e-Silva ${ }^{1}$, W.M. Cardoso ${ }^{2}$, R.V. Horn ${ }^{1}$, C.M. Cavalcanti ${ }^{1}$, A.J.F. Beleza ${ }^{1}$, C.P. Almeida,

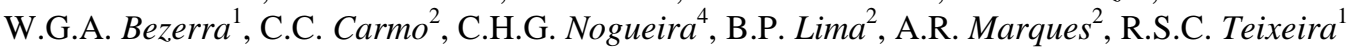 \\ ${ }^{1}$ Aluno de pós-graduação - Universidade Estadual do Ceará - Fortaleza, CE \\ ${ }^{2}$ Universidade Estadual do Ceará - Fortaleza, CE \\ ${ }^{3}$ Aluno de pós-graduação - Universidade Federal do Ceará - Fortaleza, CE \\ ${ }^{4}$ Hospital Geral de Fortaleza - Fortaleza, CE
}

\begin{abstract}
Salmonella Gallinarum is capable of causing high mortality in birds of the order Galliformes. This study aimed to relate the presence of clinical signs with the recovery of Salmonella Gallinarum from organs and c loacal swabs of Japanese quails (Coturnix coturnix) experimentally infected. A total of 70 female quails were housed in a pair per cage and divided in two groups (IG: quails inoculated with $1.5 \times 10^{6} \mathrm{CFU}$ of Salmonella Gallinarum Nal$/ \mathrm{mL}$ and CG: control group). After the inoculation, birds were evaluated three times a day to verify the presence of clinical signs. Birds that presented ruffled feathers, eyes closed and remained quiet in the cage were removed for euthanasia, as well as the same number of birds from the inoculated groups that presented no clinical signs and from the control group. Cloacal swabbing was performed following euthanasia for the sampling of liver, spleen, caeca, ovarian follicles and lung for microbiological procedure. Quails with clinical signs and quails found dead presented positivity of $100 \%$. While inoculated quails with no clinical signs presented a lower positivity (38.5\%). Therefore, quails with septicemia caused by SG present clinical signs of the disease and the pathogen can be isolated and quantified in the organs.
\end{abstract}

Keywords: immune response, isolated, mortality, clinical signs

\section{RESUMO}

Salmonella Gallinarum pode causar alta mortalidade em aves da ordem Galliformes. Objetivou-se neste estudo relacionar a presença de sinais clínicos com a recuperação de Salmonella Gallinarum de órgãos e swabs cloacais de codornas japonesas (Coturnix coturnix) experimentalmente infectadas. Um total de 70 codornas fêmeas foram alojadas em par por gaiola e divididas em dois grupos (IG: codornas inoculadas com 1,5x10 6 UFC de Salmonella Gallinarum Nalr / $\mathrm{mL}$ e CG: grupo controle). Após a inoculação, as aves foram avaliadas três vezes ao dia para se verificar a presença de sinais clínicos. As aves que se apresentaram com penas eriçadas, olhos fechados e permaneciam imóveis na gaiola foram removidas para a eutanásia, assim como o mesmo número de aves dos grupos inoculados que não apresentaram sinais clínicos e do grupo controle. $O$ swab cloacal foi realizado após a eutanásia para a amostragem de fígado, baço, ceco, folículos ovarianos e pulmão para procedimento microbiológico. As codornas com sinais clínicos e as encontradas mortas apresentaram positividade de 100\%, enquanto as codornas inoculadas sem sinais clínicos apresentaram menor positividade (38,5\%). Portanto, codornas com septicemia causada por $S G$ apresentam sinais clínicos da doença e o patógeno pode ser isolado e quantificado em diversos órgãos.

Palavras-chave: resposta imunológica, isolada, mortalidade, sinais clínicos

Recebido em 29 de março de 2017

Aceito em 6 de setembro de 2017

E-mail: robertarochavet@hotmail.com 


\section{INTRODUCTION}

Salmonella Gallinarum is capable of producing severe disease and death in birds (Chadfield et al., 2003), mainly Galliformes (Shivaprasad, 2000). Although birds aging 3 months or older are more frequently found with the disease, it can affect birds of all ages (Uzzau et al., 2000).

Among the Galliformes, quails are highlighted due to the ascension in the poultry market, caused mainly by the good food conversion (Almeida et al., 2002), high egg production (Albino \& Barreto, 2003), precocity (Barreto et al., 2007), and high prolificacy (Daikwo et al., 2011). Also, quail production requires a low investment and has a high financial return (Barreto et al., 2007).

According to Rocha-e-Silva et al. (2013), quails in productive age infected with $S$. Gallinarum present high mortality. Therefore, further studies on $S$. Gallinarum infection in these birds are important, because such disease cause great losses on quail farming, but also because there are not many studies concerning this pathogen in this bird species.

$S$. Gallinarum does not trigger a strong immune response, which allows the penetration of the pathogen without tissue damage and consequently a flaw in the host immune response (Kaiser et al., 2000). The main multiplication site of bacteria from the genus Salmonella is the digestive tract and through the bloodstream and/or lymphatic system they disseminate through the organs rich in reticuloendothelial tissue (Kabir, 2010) causing systemic infection (Chadfield et al., 2003).

This study aimed to relate the presence of clinical signs with the recuperation of Salmonella Gallinarum in organs and cloacal swabs of Japanese quails (Coturnix coturnix) experimentally infected.

\section{MATERIAL AND METHODS}

A total of 70 Japanese quails of approximately 23 weeks of age and with mean weight of $245 \mathrm{~g}$ were used in this experiment. Two birds per cage were housed in pyramid type batteries with dimensions of $22 \times 21 \times 16 \mathrm{~cm}$ and comprising a density of $43.47 \mathrm{bird} / \mathrm{m}^{2}$ located in the inoculation facilities of the Sector of Ornithological Studies, State University of Ceará. Birds were randomly divided between the following groups: Inoculated Group (IG), formed by 48 quails inoculated with the Salmonella Gallinarum strain and Control Group (CG), formed by 16 quails that received placebo. Six birds randomly selected were euthanized to confirm the absence of Salmonella spp. in organs. Water and feed were provided ad libitum with no addition of antibiotics, vaccine or parasite control medication. Temperature $\left(25.5^{\circ} \mathrm{C}\right)$ and photoperiod (16h light/day) were controlled. This study was approved by the local Ethics Committee for the Use of Animals (CEUA) with the number 10244779-9/26.

Before the experiment, a survey of Salmonella spp. in all birds was performed to guarantee that they were free of this pathogen as described by Zancan et al. (2000): individual cloacal swabs were collected soaked in Selenite-Cystine broth with novobiocin (SCNov) $(40 \mu \mathrm{g} / \mathrm{mL})$ and direct plating was performed (Oh) in Brilliant Green agar (BG). Plates were cultivated in bacteriological incubator for $24 \mathrm{~h}$ at $37^{\circ} \mathrm{C}$. After such period, negative samples for Salmonella spp. were again plated in BG and incubated for $24 \mathrm{~h}$ at $37^{\circ} \mathrm{C}$ to confirm the absence of the pathogen in these birds. Yet, another control was performed with birds selected to euthanasia, in which the organs were collected for bacteriological procedure as follows: a fragment of the liver, spleen, lung, cecum and ovarian follicles were collected aseptically, individually macerated and placed in tubes containing Buffered Peptone Water $0.1 \%$ for $24 \mathrm{~h}$ at $37^{\circ} \mathrm{C}$. After this period, an aliquot was transferred to tube containing SCNov and again incubated. Then, samples were streaked in BG and followed incubation.

The inoculum was prepared using a strain of Salmonella Gallinarum 287/91 naturally resistant to nalidixic acid $\left(\mathrm{SGNal}^{\mathrm{r}}\right)$ isolated from chickens (Gallus gallus) in an outbreak of fowl typhoid in Brazil (Thomson et al., 2008) provided by the Department of Veterinary Pathology, São Paulo State University campus in Jaboticabal (São Paulo, Brazil). The genome of this strain was sequenced (Thomson et al., 2008) and is available at the National Center of Biotechnology Information (NCBI) database 
(Genbank ID: AM933173.1). The strain was maintained at $-80^{\circ} \mathrm{C}$.

The culture was prepared according to Berchieri Júnior et al. (2001) with modifications as follows: the strain was incubated in $10 \mathrm{~mL}$ of Buffered Peptone Water $0.1 \%$ and statically incubated for $18 \mathrm{~h}$ at $37^{\circ} \mathrm{C}$. After this period, serial dilutions were performed (Miles et al., $1938)$ in brilliant green agar containing nalidixic acid $(100 \mu \mathrm{g} / \mathrm{mL})$ and novobiocin $(1 \mu \mathrm{g} / \mathrm{mL})(B G$ $\mathrm{Nal} / \mathrm{Nov})$ and incubated at $37^{\circ} \mathrm{C}$ for $24 \mathrm{~h}$ to determine Colony Forming Units (CFU). Once established, an inoculum containing $1.5 \times 10^{6}$ CFU of Salmonella Gallinarum $\mathrm{Nal}^{\mathrm{r}} / \mathrm{mL}$.

Birds of the IG and CG received a $0.7 \mathrm{~mL}$ inoculum and $0.7 \mathrm{~mL}$ saline solution, respectively via gavage, directly in the crop, with the aid of a cannula coupled to a $1 \mathrm{~mL}$ syringe.

After the inoculation, birds were evaluated in three daytimes $(8: 00,11: 00$ and 14:00) to verify the presence of clinical signs (bird quiet in the corner of the cage, eyes closed and ruffled feathers). At the sight of any symptom, the bird passed to the symptomatic inoculated group (SIG) and was removed to the cage for cloacal swab sampling, following euthanasia for macroscopic evaluation and organ collection (liver, spleen, caeca, ovarian follicles and lung) for CFU counting (Miles et al., 1938).

For every SIG bird destined for euthanasia one bird from the CG and one bird from the IG with no clinical symptoms were randomly selected for the same tests, which formed the no symptoms group (NSG). IG quails found dead during the observation period originated the dead group (DG). These birds were necropsied and organs were collected for microbiological procedure. In this group, no CFU counting or cloacal swab was performed.

When no clinical symptoms were observed, or mortality (Rocha-e-Silva et al., 2013), euthanasia was performed in the remaining birds. First, individual cloacal swabs, following euthanasia were performed for the aseptic collection of the organs (liver, spleen, caeca, ovarian follicles and lung) for microbiological evaluation.

Sterile swabs soaked in SCNov $(40 \mu \mathrm{g} / \mathrm{mL})$ were used, following direct plating in BGNal
$(100 \mu \mathrm{g} / \mathrm{mL})$ after collection. Samples were placed in bacteriological incubator for $24 \mathrm{~h}$ and $37^{\circ} \mathrm{C}$ and after that period, negative samples for Salmonella Gallinarum (SG) were again plated in BGNal $(100 \mu \mathrm{g} / \mathrm{mL})$.

Following euthanasia, necropsy was performed for the sampling of spleen, liver, lung, cecum and ovarian follicles for CFU counting. Organs destined to microbiological procedure were aseptically removed, macerated individually, weighed and transferred to Buffered Peptone Water $0.1 \%(1 \mathrm{~g} / 10 \mathrm{~mL})$ for the serial dilutions $\left(10^{1}-10^{6}\right)$. When no bacterial growth was observed, in which case the CFU counting was not possible, an aliquot of the culture was transferred to SCNov $(40 \mu \mathrm{g} / \mathrm{mL})$ and incubated for $24 \mathrm{~h}$ at $37^{\circ} \mathrm{C}$. After this period, samples were plated in BGNal $(100 \mu \mathrm{g} / \mathrm{mL})$ and incubated for the same period and temperature. Dead birds were also necropsied and organs removed for microbiological procedure as follows: organs were aseptically removed, individually macerated and transferred to tubes containing Buffered Peptone Water $0.1 \%$ incubated at $24 \mathrm{~h}$ at $37^{\circ} \mathrm{C}$. Then, an aliquot was transferred to SCNov $(40 \mu \mathrm{g} / \mathrm{mL})$ and incubated for $24 \mathrm{~h}$ at $37^{\circ} \mathrm{C}$. After that period, samples were streaked in BGNal $(100 \mu \mathrm{g} / \mathrm{mL})$ and incubated as previously established. Samples that did not present colonies with typical morphological profile of SG, which are small colonies (2-4mm), smooth edges and circular shape (Bergey et al., 1994), were submitted to an agglutination test using polyvalent $\mathrm{O}$ antiserum poly (Difco®).

The non-parametric test chi-square with Yates correction or the Fisher's exact test, when indicated, with a significance of $5 \%$ were used to compare the number of positive $\mathrm{SG}$ organ samples between the experimental groups.

\section{RESULTS}

Cloacal swab samples from all birds and organs of birds euthanized at the beginning of the experiment did not show any evidence of Salmonella spp.

During the experimental period, deaths occurred from the $5^{\text {th }}$ day post-inoculation (dpi) onwards, with a total of 19 deaths from the groups of birds inoculated with Salmonella Gallinarum (GO) and none from the control group. However, at the 
$11^{\text {th }}$ dpi, clinical signs were no longer observed, which marked the last day of experiment.

From the 48 inoculated quails that survived, 13 $(27.1 \%)$ presented clinical signs. Therefore, these birds formed the NSG group and other 13 birds inoculated with placebo were kept as control. At the end of the experiment, three inoculated birds and three GI birds remained. All of which were euthanized and presented negative swab and organ samples.

All birds from the SIG (symptomatic) and birds found dead were positive, while birds from the NSG (with no symptoms) presented a lower positive rate of $38.5 \%$. However, from the control group, $100 \%$ of the birds were negative.

Table 1 present the results from the bacteriological procedure of the cloacal swabs and organs of birds that were euthanized and the ones found dead. No significant difference was observed $(\mathrm{P}>0.05)$ between the organ samples positive for SG of the SIG and DG groups, with the exception of the lung samples, of which all birds from the SIG group were positive in all organs, while in the DG group only 12 (63.16\%) were positive. Quails from the NSG presented a significantly lower rate of isolation in all organs analyzed.

Table 01. Isolation of Salmonella Gallinarum from Japanese quails experimentally inoculated with $1.5 \times 10^{6} \mathrm{CFU} / \mathrm{mL}$

\begin{tabular}{ccccccc}
\hline \multirow{2}{*}{ Organs } & \multicolumn{2}{c}{ NSG } & \multicolumn{2}{c}{ SIG } & \multicolumn{2}{c}{ DG } \\
\cline { 2 - 7 } & $\mathrm{n}$ & $\%$ & $\mathrm{n}$ & $\%$ & $\mathrm{n}$ & $\%$ \\
\hline Liver & $4 / 13^{\mathrm{a}}$ & 30,8 & $13 / 13^{\mathrm{b}}$ & 100,0 & $19 / 19^{\mathrm{b}}$ & 100,0 \\
Spleen & $4 / 13^{\mathrm{a}}$ & 30,8 & $12 / 13^{\mathrm{b}}$ & 92,3 & $19 / 19^{\mathrm{b}}$ & 100,0 \\
Cecum & $1 / 13^{\mathrm{a}}$ & 7,7 & $7 / 13^{\mathrm{b}}$ & 53,9 & $9 / 19^{\mathrm{b}}$ & 47,4 \\
Ovary & $3 / 13^{\mathrm{a}}$ & 23,1 & $13 / 13^{\mathrm{b}}$ & 100,0 & $19 / 19^{\mathrm{b}}$ & 100,0 \\
Lung & $3 / 13^{\mathrm{a}}$ & 23,1 & $13 / 13^{\mathrm{c}}$ & 100,0 & $12 / 19^{\mathrm{b}}$ & 63,16 \\
Swab & $0 / 13^{\mathrm{a}}$ & 0 & $4 / 13^{\mathrm{b}} *$ & 30,8 & $\mathrm{NP}$ & $\mathrm{NP}$ \\
Total positive birds & $5 / 13$ & 38,5 & $13 / 13$ & 100,0 & $19 / 19$ & 100 \\
\hline
\end{tabular}

$\mathrm{NP}$ - Not performed

* after incubation in selenite broth

abc Significant differences $(\mathrm{P}<0,05)$ between groups of positive birds of different treatments

Among the organs analyzed, the caeca was the organ with the lowest frequency of strain recuperation, presenting the lowest isolation rate from the NSG group (23.1\%) and the highest from the SIG group (53.9\%). The highest positive results from the liver, spleen, ovarian follicles, and lung samples were observed among the quails from SIG and DG groups. Quails presented an $100 \%$ isolation from these organs, with the exception of the SIG group, in which a recuperation rate of $92.3 \%$ was observed. SG was recuperated from cloacal swabs of four inoculated birds that presented clinical signs of the disease.

CFU were successfully counted from almost all organs of birds from the SIG group, with the exception of six samples of caeca and one lung and spleen sample (Table 2). Between the NSG quails, CFU counting from organ samples was possible only in two quails, which were liver, spleen and ovary. From cecum and lung, counting was possible only in one bird. From two liver and spleen samples, as well as in one ovary and lung sample, the pathogen was recovered after incubation of the pre-enrichment and selective enrichment broths. The bacterial counting from bird organs that presented clinical signs was higher than birds that did not present it (Table 3).

Among the alterations observed in the experimental birds, the SIG and DG groups presented the highest macroscopic alteration rates. Spleen enlargement $(84.6 \%)$ and liver necrosis $(30.8 \%)$ were the most frequent alterations in the SIG group, while the DG group presented frequencies of $100 \%$ and $89.5 \%$, respectively. The highest rate observed in the NSG group was of liver enlargement, 38.5\% (Table 4). From the control group, no macroscopic alterations were observed. 
Relationship between clinical...

Table 2. Salmonella Gallinarum detected in organ and cloacal swab samples of Japanese quails with clinical signs

\begin{tabular}{|c|c|c|c|c|c|c|c|}
\hline \multirow{2}{*}{ Bird } & \multicolumn{6}{|c|}{ Number $(\log 10)$ of viable cells from samples } & \multirow{2}{*}{ Dpi } \\
\hline & Liver & Spleen & Cecum & Ovary & Lung & Swab & \\
\hline 49 & 4,70 & 5,00 & 3,98 & 5,00 & 3,90 & - & 4 \\
\hline 1 & 4,48 & 4,34 & 3,30 & 3,48 & 3,54 & - & 5 \\
\hline 2 & 4,30 & 4,81 & - & 3,48 & 4,18 & - & 5 \\
\hline 3 & 4,54 & 5,00 & 2,00 & 3,40 & 4,30 & - & 5 \\
\hline 56 & 5,00 & 5,18 & - & 4,00 & 3,30 & - & 5 \\
\hline 64 & 5,30 & 4,70 & 4,40 & 5,40 & 5,34 & - & 5 \\
\hline 67 & 4,30 & 4,00 & - & 2,70 & 2,70 & + & 5 \\
\hline 12 & 5,60 & 5,74 & - & 5,54 & 4,74 & + & 6 \\
\hline 13 & 5,20 & - & - & 4,56 & 4,85 & - & 6 \\
\hline 19 & 5,90 & 6,20 & - & 5,93 & + & - & 6 \\
\hline 21 & 5,78 & 5,93 & 2,54 & 4,66 & 4,62 & + & 6 \\
\hline 57 & 4,85 & 4,88 & 3,70 & 3,93 & 4,08 & - & 6 \\
\hline 48 & 6,23 & 6,11 & 4,81 & 5,81 & 5,81 & + & 7 \\
\hline
\end{tabular}

+ Samples positive after pre-enrichment and selective enrichment

Table 3. Salmonella Gallinarum from organ and cloacal swab samples of Japanese quails with no clinical signs

\begin{tabular}{|c|c|c|c|c|c|c|c|}
\hline \multirow{2}{*}{ Bird } & \multicolumn{6}{|c|}{ Number $(\log 10)$ of viable cells from samples } & \multirow{2}{*}{ Dpi } \\
\hline & Liver & Spleen & Cecum & Ovary & Lung & Swab & \\
\hline 55 & - & - & - & - & - & - & 4 \\
\hline 27 & 4,95 & 4,18 & 4,93 & 4,54 & 4,54 & - & 5 \\
\hline 53 & - & - & - & - & - & - & 5 \\
\hline 54 & - & - & - & - & - & - & 5 \\
\hline 58 & 2,74 & 5,08 & - & 2,70 & - & - & 5 \\
\hline 59 & - & + & - & - & + & - & 5 \\
\hline 60 & - & - & - & - & - & - & 5 \\
\hline 7 & + & + & - & - & + & - & 6 \\
\hline 15 & + & - & - & + & - & - & 6 \\
\hline 30 & - & - & - & - & - & - & 6 \\
\hline 50 & - & - & - & - & - & - & 6 \\
\hline 62 & - & - & - & - & - & - & 6 \\
\hline 29 & - & - & - & - & - & - & 7 \\
\hline
\end{tabular}

+ Samples positive after pre-enrichment and selective enrichment

Table 4. Macroscopic alterations observed in Japanese quails experimentally inoculated with Salmonella Gallinarum

\begin{tabular}{ccccccccccc}
\hline \multirow{2}{*}{ Groups } & Alteration & \multicolumn{9}{c}{ Organs } \\
\cline { 3 - 10 } & & \multicolumn{2}{c}{ Liver } & \multicolumn{2}{c}{ Spleen } & \multicolumn{2}{c}{ Ovary } & \multicolumn{2}{c}{ Cecum } \\
\hline \multirow{3}{*}{ NSG } & & $\mathrm{n}$ & $(\%)$ & $\mathrm{n}$ & $\%$ & $\mathrm{n}$ & $\%$ & $\mathrm{n}$ & $\%$ \\
\cline { 3 - 11 } & Hypertrophy & $1 / 13$ & $(7,7)$ & $5 / 13$ & $(38,5)$ & $0 / 13$ & $(0,0)$ & $0 / 13$ & $(0,0)$ \\
& Hemorrhage & $2 / 13$ & $(15,4)$ & $1 / 13$ & $(7,7)$ & $0 / 13$ & $(0,0)$ & $0 / 13$ & $(0,0)$ \\
\hline \multirow{2}{*}{ SIG } & Hypertrophy & $2 / 13$ & $(15,4)$ & $11 / 13$ & $(84,6)$ & $0 / 13$ & $(0,0)$ & $0 / 13$ & $(0,0)$ \\
& Necrosis & $4 / 13$ & $(30,8)$ & $0 / 13$ & $(0,0)$ & $0 / 13$ & $(0,0)$ & $0 / 13$ & $(0,0)$ \\
& Hemorrhage & $1 / 13$ & $(7,7)$ & $1 / 13$ & $(7,7)$ & $1 / 13$ & $(7,7)$ & $0 / 13$ & $(0,0)$ \\
& Petechiae & $0 / 13$ & $(0,0)$ & $2 / 13$ & $(15,4)$ & $0 / 13$ & $(0,0)$ & $0 / 13$ & $(0,0)$ \\
\hline \multirow{2}{*}{ DG } & Hypertrophy & $17 / 19$ & $(89,5)$ & $19 / 19$ & $(100,0)$ & $0 / 19$ & $(0,0)$ & $0 / 13$ & $(0,0)$ \\
& Necrosis & $1 / 19$ & $(5,3)$ & $0 / 19$ & $(0,0)$ & $0 / 19$ & $(0,0)$ & $0 / 13$ & $(0,0)$ \\
& Hemorrhage & $0 / 19$ & $(0,0)$ & $1 / 19$ & $(5,3)$ & $0 / 19$ & $(0,0)$ & $1 / 19$ & $(5,3)$ \\
\hline
\end{tabular}




\section{DISCUSSION}

In this study, quails presented clinical signs typical of SG infection at the $4^{\text {th }} \mathrm{dpi}$, as it was observed by Audisio and Terzolo (2002), whom verified that chickens inoculated with SG presented clinical signs after the $4^{\text {th }}$ dpi. However, Garcia et al. (2010) observed that depending on the concentration used, layer hens may present clinical signs earlier at the $3^{\text {rd }} \mathrm{dpi}$.

Not considering the euthanized birds (NSG and SIG), in which the mortality did not occur due to the inoculation, the death rate was $85.71 \%$. The mortality of birds inoculated with SG is very high, reaching $80 \%$ in chicken flocks (Paiva et al., 2009) and $94.7 \%$ in quail flocks (Rocha-eSilva et al., 2013). Usually the mortality of birds inoculated with SG begins at the $5^{\text {th }} \mathrm{dpi}$ (Berchieri Júnior et al., 2000; Freitas Neto et al., 2007), with mortality peak at the $10^{\text {th }} \mathrm{dpi}$ (Audisio and Terzolo, 2002) and in susceptible birds the mortality can extend until the $11^{\text {th }} \mathrm{dpi}$ (Freitas Neto et al., 2007). At the $11^{\text {th }} \mathrm{dpi}$, the pathogen cannot be isolated from birds infected with SG that do not present clinical signs of the disease (Rocha-e-Silva et al., 2013), however hens that recover from Salmonella Pullorum infection show little sign of disease but produce strong antibody response (Wigley et al., 2001).

The highest recovery rates of SG from organs of analyzed quails always occurred in the groups that presented clinical signs or death, which suggests that the experimental inoculation performed is capable of producing septicemia and lead to death. Some authors reported that close to death, the possibility of isolating SG is higher (Oliveira et al., 2005; Freitas Neto et al., 2007) which may explain the higher recovery rate of the pathogen in the birds that presented signs of salmonellosis when compared to the quails that did not present. The study of Rocha-eSilva et al. (2013) also reinforces the hypothesis that mortality occurred in quails inoculated with SG is due to the septicemia previously established, since they verified that all birds found dead presented positive in the microbiological analysis of caeca, lung, reproductive tract or spleen samples as well as classic signs of fowl typhoid.

All birds that presented clinical signs of SG infection presented diarrhea, but not all birds from which the pathogen was isolated presented diarrhea. Among the quails that did not present clinical signs characterized in this study and were positive for SG, two presented diarrhea which was observed after the cloacal swabbing. Although diarrhea is a clinical sign characteristic of Salmonella Gallinarum infection, the main signs observed are depression, weakness, loss of appetite, ruffled feathers, dropped wings and eyes closed (Freitas Neto et al., 2007).

From these two birds, the CFU counting was possible in the organs, confirming that the bacteria had already spread through the entire animal's organism and it was multiplying itself. However, due to the characteristic of the pathogen of not causing tissue damage enough for stimulating an adequate immune response by the host (Kaiser et al., 2000), the birds did not develop all the clinical signs of the disease, which made the diarrhea, probably, the first of them. According to Oliveira et al. (2005), when experimenting on brown adult hens, diarrhea was observed in the first days post-inoculation with SG and birds maintained their normal behavior, which was eating, drinking and laying eggs regularly, demonstrating that the presence of diarrhea was not an evidence that the bird was near death, although presenting septicemia.

Although the cecum is the most suitable location for some Salmonella, SG has little capacity of colonizing this organ (Setta et al., 2012). This may justify the low recovery rate of SG in quails in relation to the other organs analyzed. According to Berndt et al. (2007), some bacterial structures may be involved such as initiators of adhesion and/or invasion of the digestive tract epithelium. The flagella are a structural component of the microorganisms important to this invasion (Dibb-Fuller \& Woodward, 2000) and SG does not possess it, which makes the invasion of the caeca harder.

The cloacal swabs indicated a lower recovery SG rate $(4: 26)$ in relation to the microbiological analysis of the sampled organs. Probably due to the insufficient volume of feces collected individually with the swabs to detect the pathogen. However, with a larger amount of fecal sample sometimes to recover SG from infected birds is also not possible (Rocha-e-Silva et al., 2013), even with an inoculum of the same concentration. According to Ishola (2009) the 
fecal excretion, either analyzed from feces or cloacal swabbing, is a parameter used to evaluate the infectious process, with a decline in the excretion rate indicative of a reduction at the levels of systemic infection in birds, whether through humoral or cellular response. But according to what was observed in this study, similar to what was observed by Rocha-e-Silva et al. (2013), this indication is flawed when Salmonella Gallinarum is involved, because, the infected bird may not excrete the pathogen in the feces or swabs, however organs may present the bacteria.

The macroscopic alterations observed in the bids of this study were related to the liver and spleen, which is justifiable since the bacteria of the genus Salmonella replicate mostly in these organs causing hepatosplenomegaly (Chappell et al., 2009), but also necrotic foci and hemorrhage in liver and spleen of birds with fowl typhoid (Berchieri Júnior et al., 2000; Rocha-e-Silva et al., 2013).

The birds that did not present clinical signs and their respective organ samples analyzed showed positive for SG only after pre-enrichment and selective enrichment probably overcame the acute phase of the infection, since the pathogen was successfully recovered on after the $5^{\text {th }} \mathrm{dpi}$ and only in a few birds. At the moment, postacute phase, the number of microorganisms normally declines, mainly in the spleen and liver (Chappell et al., 2009). Therefore, the splenomegaly observed in these birds confirms that they developed a satisfactory immune response against the infectious agent and were recovering (Chappell et al., 2009).

\section{CONCLUSION}

Quails with septicemia caused by SG present clinical signs of the disease, which makes the isolation and quantification of the agent in the organs possible. Although presenting clinical signs of the infection and high number of the pathogen in the organs, it is hard to isolate the pathogen from cloacal swabs. Quails with fowl typhoid may not excrete the pathogen, even when they are close to death.

\section{ACKNOWLEDGEMENTS}

The authors are grateful to Coordenação de Aperfeiçoamento de Pessoal de Nível Superior (CAPES) for financial support and the Laboratório de Estudos Ornitológicos (LABEO/FAVET/UECE) for their support to this study and Universidade de São Paulo (Unesp), Faculdade de Medicina Veterinária e Agronomia, Jaboticabal, Brazil.

\section{REFERENCES}

ALBINO, L.F.T.; BARRETO, S.L.T. Criação de codornas para produção de ovos e carnes. Viçosa, MG: Aprenda Fácil, 2003. 289p.

ALMEIDA, M.I.M.; OLIVEIRA, E.G.; RAMOS, P.R.; VEIGA, N.; DIAS, K. Growth performance of meat male quails (coturnix sp.) of two lines under two nutritional environments. Arch. Vet. Sci., v.7, p.103108,2002

AUDISIO, M.C.; TERZOLO, H.R. Virulence analysis of a Salmonella Gallinarum strain by oral inoculation of 20-day-old chickens. Avian Dis., v.46, p.186-191, 2002.

BARRETO, S.L.T.; QUIRINO, B.J.S.; BRITO, C.O. et al. Níveis de energia metabolizável para codornas japonesas na fase inicial de postura. Rev. Bras. Zootec., v.36, p.79-85, 2007.

BERCHIERI JÚNIOR, A.; MURPHY, A.; MARSTON, K.; BARROW, P.A. Observations on the persistence and vertical transmission of Salmonella enterica serovars Gallinarum and Pullorum in chickens: effect of bacterial and host genetic background. Avian Pathol., v.30, p.221-231, 2001

BERCHIERI JÚNIOR, A.; OLIVEIRA, G.H.; PINHEIRO, L.A.S.; BARROW, P.A. Experimental Salmonella Gallinarum infection in light laying hen lines. Braz. J. Microbiol., v.31, p.50-52, 2000

BERGEY, D.H.; HOLT, J.G.; KRIEG, N.R. Bergey's: manual of determinative bacteriology. 9.ed. Baltimore: Williams \& Wilkins, 1994. 787p.

BERNDT, A.; WILHELM, A.; JUGERT, C. et al. Chicken cecum immune response to Salmonella enterica serovars of different levels of invasiveness. Infect. Immun., v.75, p.5993-6007, 2007.

CHADFIELD, M.S.; BROWN, D.J.; AABO, S. et al. Comparison of intestinal invasion and macrophage response of Salmonella Gallinarum and other hostadapted Salmonella enterica serovars in the avian host. Vet. Microbiol., v.92, p.49-64, 2003. 
CHAPPELL, L.; KAISER, P.; BARROW, P. et al. The immunobiology of avian systemic salmonellosis. Vet. Immunol. Immunopathol., v.128, p.53-59, 2009.

DAIKWO, S.I.; DIM, N.I.; MOMOH, M.O. Hatching characteristics of Japanese quail eggs in a tropical environment. Int. J. Poult. Sci., v.10, p.876-878, 2011.

DIBB-FULLER, M.P.; WOODWARD, M.J. Contribution of fimbriae and flagella of Salmonella enteritidis to colonization and invasion of chicks. Avian Pathol., v.29, p.295-304, 2000.

FREITAS NETO, O.C.; ARROYAVE, W.; ALESSI, A.C. et al. Infection of commercial laying hens with Salmonella Gallinarum: clinical, anatomopathological and haematological studies. Braz. J. Poult. Sci., v.9, p.133-141, 2007

GARCIA, K.O.; SANTANA, A.M.; FREITAS NETO, O.C. et al. Experimental infection of commercial layers using a Salmonella enterica sorovar Gallinarum strain: blood serum components and histopathological changes. Braz. J. Vet. Pathol., v.3, p.111-117, 2010.

ISHOLA, O.O. Effects of challenge dose on faecal shedding of Salmonella Enteritidis in experimental infected chickens. Afr. J. Biotechnol., v.8.p.13431346, 2009.

KABIR, S.M.L. Avian Colibacillosis and Salmonellosis: a closer look at epidemiology, pathogenesis, diagnosis, control and public health concerns. Int. J. Environ. Res. Public Health, v.7, p.89-114, 2010.

KAISER, P.; ROTHWELL, L.; GALYOV, E.E. et al. Differential cytokine expression in avian cells in response to invasion by Salmonella typhimurium, Salmonella enteritidis and Salmonella gallinarum. Microbiology, v.146, p.3217-3226, 2000.

MILES, A.A.; MISRA, S.S.; IRWIN, J.O. The estimation of the bactericidal power of the blood. $J$. Hyg., v.38, p.732-749, 1938.

OLIVEIRA, G.H.; BERCHIERI JR, A.; FERNANDES, A.C. Experimental infection of laying hens with Salmonella enterica serovar Gallinarum. Braz. J. Microbiol., v.36, p.51-56, 2005.
PAIVA, J.B.; PENHA FILHO, R.A.C.; ARGÜELLO, Y.M.S. et al. Efficacy of several Salmonella vaccination programs against experimental challenge with Salmonella Gallinarum in commercial brown layer and broiler breeder hens. Braz. J. Poult. Sci., v.11, p.65-72, 2009.

ROCHA-E-SILVA, R.C.; CARDOSO, W.M.; TEIXEIRA, R.S.C. et al. Salmonella Gallinarum virulence in experimentally-infected japanese quails (Coturnix japonica). Braz. J. Poult. Sci., v.15, p.233238, 2013.

SETTA, A.M.; BARROW, P.A.; KAISER, P.; JONES, M.A. Early immune dynamics following infection with Salmonella enterica serovars Enteritidis, Infantis, Pullorum and Gallinarum: cytokine and chemokine gene expression profile and cellular changes of chicken cecal tonsils. Comp. Immunol. Microbiol. Infect. Dis., v.35, p.397-410, 2012.

SHIVAPRASAD, H.I. Fowl typhoid and pullorum disease. Rev. Sci. Technol., v.19, p.405-424, 2000.

THOMSON, N.R.; CLAYTON, D.J.; WINDHORST, D. et al. Comparative genome analysis of Salmonella enteritidis PT4 and Salmonella gallinarum 287/91 provides insights into evolutionary and host adaptation pathways. Genome Res., v.18, p.1624-1637, 2008.

UZZAU, S.; BROWN, D.J.; WALLIS. T. et al. Host adapted serotypes of Salmonella enterica. Epidemiol. Infect., v.125, p.229-255, 2000.

WIGLEY, P.; BERCHIERI JR, A.; PAGE, K.L. et al. Salmonella enterica serovar Pullorum persists in splenic macrophages and in the reproductive tract during persistent disease-free carriage in chickens. Infect. Immun., v.69, p.7873-7879, 2001.

ZANCAN, F.T.; BERCHIERI JR, A.; FERNANDES, S.A.; GAMA, N.M.S.Q. Salmonella investigation in transport boxes of day-old birds. Braz. J. Microbiol., v.31, p.230-232, 2000. 